PERM JOURNAL OF PETROLEUM AND MINING ENGINEERING

ВЕСТНИК ПНИПУ. ГЕОЛОГИЯ. НЕФТЕТАЗОВОЕ И ГОРНОЕ ДЕЛО

ISSN 2224-9923

Volume/ Том 17 №1 2018

http://vestnik,pstu.ru/geo/

УДК 622.276.58:519.2

Article / Статья

(C) PNRPU / ПНИПУ, 2018

\title{
USE OF PROBABILISTIC AND STATISTICAL METHODS FOR DETERMINATION OF THE SOURCES OF WATER FLOW IN CANDIDATE WELLS FOR WATER SHUT-OFF WORKS (ON EXAMPLE OF THE VISEAN RESERVOIR OF THE PERM REGION FIELD)
}

\section{Darya A. Kudryashova}

Perm National Research Polytechnic University (29 Komsomolskiy av., Perm, 614990, Russian Federation)

\section{ИСПОЛЬЗОВАНИЕ ВЕРОЯТНОСТНО-СТАТИСТИЧЕСКИХ МЕТОДОВ ДЛЯ ОПРЕДЕЛЕНИЯ ИСТОЧНИКОВ ОБВОДНЕНИЯ СКВАЖИН-КАНДИДАТОВ ДЛЯ ВОДОИЗОЛЯЦИОННЫХ РАБОТ (НА ПРИМЕРЕ ВИЗЕЙСКОГО ОБЪЕКТА МЕСТОРОЖДЕНИЯ ПЕРМСКОГО КРАЯ)}

\section{Д.А. Кудряшова}

Пермский национальный исследовательский политехнический университет (614990, Россия, г. Пермь, Комсомольский пр., 29)

Received / Получена: 16.10.2017. Accepted / Принята: 01.02.2018. Published / Опубликована: 30.03.2018

\section{Key words:}

Visean reservoir, well, watercut, water shut-off works, source of water inflow, water breakthrough along the productive formation, pumped water, aquifer water, Student's $t$-criterion, distance from the lower perforation object to the water-oil contact, thickness of water inflow interval, curren density of water produced, discriminant analysis, Wilks' Lambda, classification function, posteriori probability.
Today, the problem of production of surplus associated water is particularly actual because of transition of fields to the final stages of development. Water shut-off works are the main method to combat the increased water cut of wells of modern fields. One of the most important stages in water shut-off works is the selection of candidate wells and determination of their sources of water inflow which depend on the geological structure of an oil reservoir and well technical state. Technical reasons of water inflow to wells include leakage of a production string and annular circulation. Geological reasons include lift of water-oil contact to the bottom hole, breakthrough of water along the productive formation, fractures between wells or formations.

The article discusses production wells of the Visean reservoir of the Perm region field with shut-off works done. Wells are divided according to the most common sources of water inflow into two groups such as a breakthrough in the productive formation of pumped or aquifer water. To analyze the average values of geological and technological parameters of the two groups of wells obtained from the field data the Student's $t$-criterion is used. Among the analyzed parameters the distance from the lower perforation to the water-oil contact, formation thickness and thickness of the interval of water inflow are statistically significant.

To determine the sources of water inflow for 19 candidate wells of the Visean reservoir of the Perm region field a discriminant analysis is performed. Based on the table of values of a posteriori probabilities, it is revealed that 4 wells of 19 candidate wells for water shut-off works are flooded due to breakthroughs of pumped water through the productive formation, 4 wells are flooded by aquifer water. The 11 remaining candidate wells are likely to have another source of water.

В настоящее время проблема добычи избыточной попутно-добываемой воды стоит особенно остро по причине перехода объектов месторождений на заключительные стадии разработки. Водоизоляционные работы являются основным способом борьбы с повышенной обводненностью скважин современных месторождений. Один из важнейших этапов реализации водоизоляционных работ - подбор скважин-кандидатов и определение их источников обводнения, которые зависят от геологического строения нефтяной залежи и технического состояния скважины. К техническим причинам обводнения скважин относятся негерметичность эксплуатационной колонны и заколонная циркуляция, к геологическим причинам - подъем водонефтяного контакта к интервалу вскрытия пласта, прорыв воды по продуктивному пласту, трещины между скважинами или пластами.

В данной статье рассмотрены добывающие скважины визейского объекта одного из месторождений Пермского края с выполненными водоизоляционными работами. Скважины разделены на две группы согласно наиболее часто встречающимся источникам обводнения: прорыв по продуктивному пласту нагнетаемой или законтурной воды. Для анализа средних значений геолого-технологических параметров двух групп скважин, полученных по промысловым данным, использован $t$-критерий Стьюдента. Среди анализируемых параметров статистически значимыми являются расстояние от нижнего перфорационного отверстия до водонефтяного контакта, толщина пласта и толщина интервала водопритока.

Для определения источников обводнения 19 скважин-кандидатов визейского объекта рассматриваемого месторождения Пермского края проведен дискриминантный анализ. На основании таблицы значений апостериорных вероятностей выявлено, что из 19 скважин-кандидатов для водоизоляционных работ 4 скважины обводняются за счет прорывов нагнетаемой воды по продуктивному пласту, 4 скважины - за счет законтурной воды; 11 оставшихся скважин-кандидатов, вероятнее всего, имеют другой источник обводнения.

Darya A. Kudryashova $-3^{\text {rd }}$ year PhD student at the Department of Oil and Gas Geology (tel.: +007 982453 40 48, e-mail: kudryashovada@mail.ru).

Кудряшова Дарья Анатольевна - аспирант третьего курса кафедры геологии нефти и газа (тел.: +007 982453 40 48, e-mail: kudryashovada@mail.ru). 


\section{Introduction}

A large number of deposits in particular the fields of the Volga-Ural oil and gas province today are in the final stages of development and characterized by a high percentage of production water cut. Operators around the world suffer the similar problems. Due to water flowing into a well remaining reserves are not involved in recovery which inhibit achievement of design oil recovery factor and increase the costs of its extraction, processing and recycling dramatically.

The reasons for surplus water presented in each individual well may be different, as with the ways to eliminate them. However, water shut off jobs are the all around technique [1].

The Visean reservoir the one of Perm region fields is promising for water shut off planning since it accounts for a significant amount of residual recoverable reserves and the average water cut of well production reached $93 \%$. Such a value of water cut negatively affects the profit of oil production and development of reserves (Fig. 1).

Thus, in order to increase the economic effectiveness of the development of the Visean reservoir of the field considered a large number of treatments of water shut off is necessary. The effect of such treatments directly depends on the rational choice of candidate wells and correct determination of their source of water [2-7].

The paper shows the application of probabilitystatistical methods for determining the sources of water inflow to candidate wells of the Visean reservoir of one of Perm region fields. Application of methods to solve similar problems is given in the papers [8-11] and can often be the only possible way because of the lack of appropriate studies of candidate wells. In order to perform the analysis several variables have been selected that are as follows: permeability, porosity, compartmentalization, sandiness, net oil-bearing thicknesses, oil viscosity, reservoir pressure, formation thickness, water inflow interval,

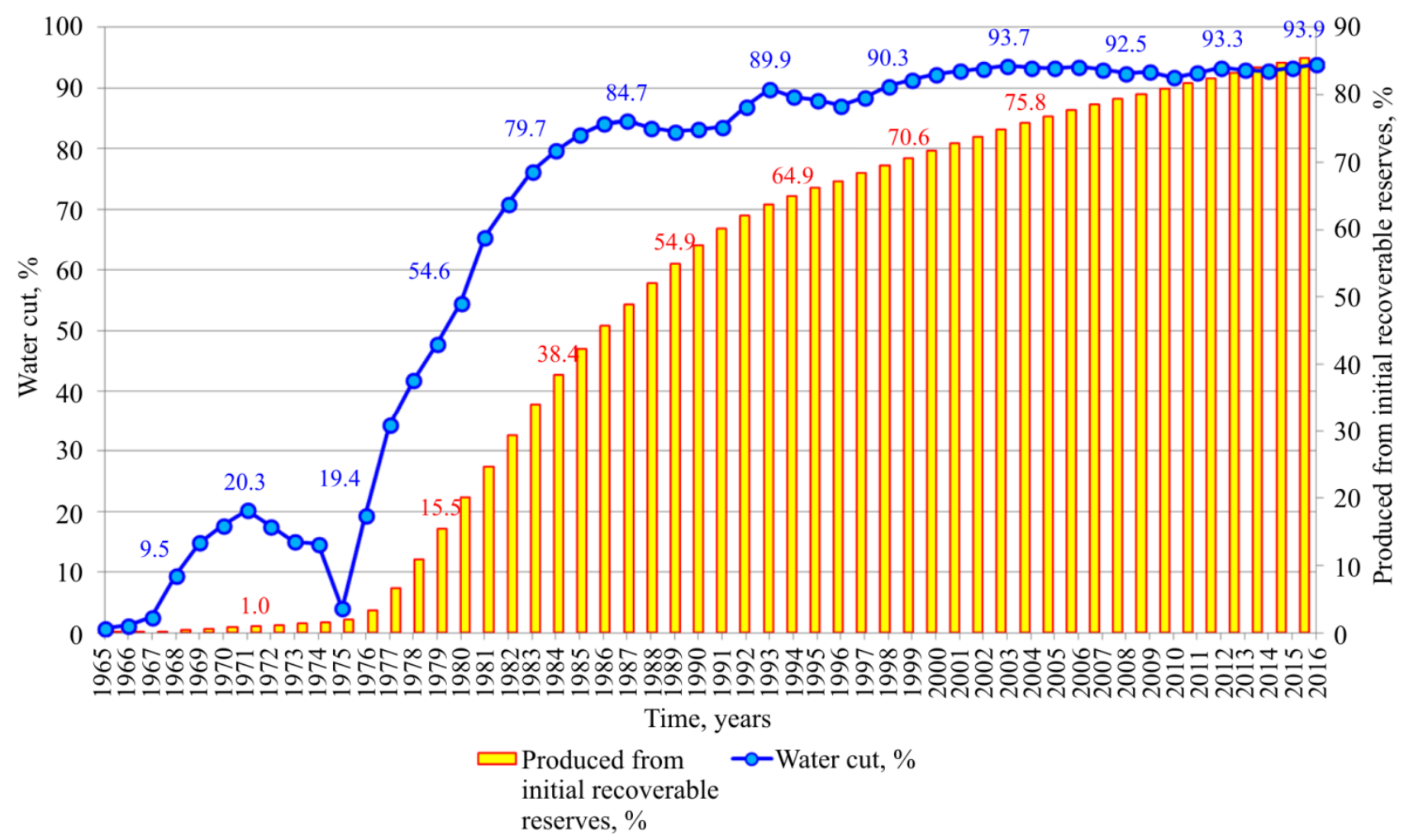

Fig. 1. Dynamics of water cut and production from initial recoverable reserves for the Visean reservoir of one of Perm region fieldst 
distance from the lower perforation holes to a water-oil contact (WOC), current density of the water produced.

\section{Classification of water cut sources in production wells}

Sources of water cut are determined by the oil field geological structure and technical state of a well. Poor technical state is the cause for emergence of foreign water in a well, which include water of the upper and lower (in relation to a reservoir) layers that do not have a hydrodynamic connection with the reservoir under natural conditions. Flow of foreign water into production wells can occur in cases when cement ring has leaks through the annular circulation and in case when production string has leaks at the intervals with water-saturated rocks.

Annular circulation appear due to poor quality of production string cementation or failure of the cement ring integrity during well operations $[2,4$
6] when flowing throug the cement stone, "cementrock", "cement-string" contacts and gradual flooding of water channels under the pressure between layers saturated with water and oil.

Loss of airtightness of a production string can be associated with corrosion of pipes in corrosive environments, mechanical defects during downhole operations and damage during operations under the high pressures. This type of water cut increase is one of the most common at the late stage of development of oil fields (Fig. 2) [2, 4-7].

Reasons for water cut increase in a secod group are related to the oil reservoir geological structure, when surplus water enters production wells through reservoirs [5]. Geological reasons for water cut increase during the field development have been studied by many researchers $[2,6,12-$ 16 and others]. It is revealed that the main reason for premature increase in water cut of production wells with incomplete recovery of reserves is heterogeneous permeability of layers.

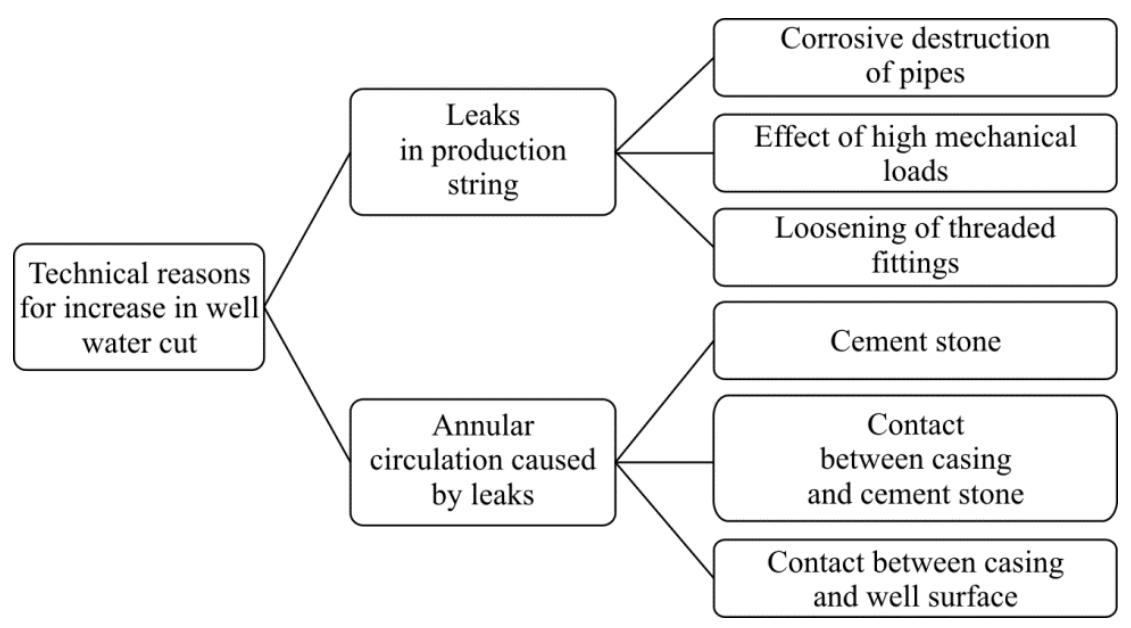

Fig. 2. Classification of technical reasons for increase in well water cut

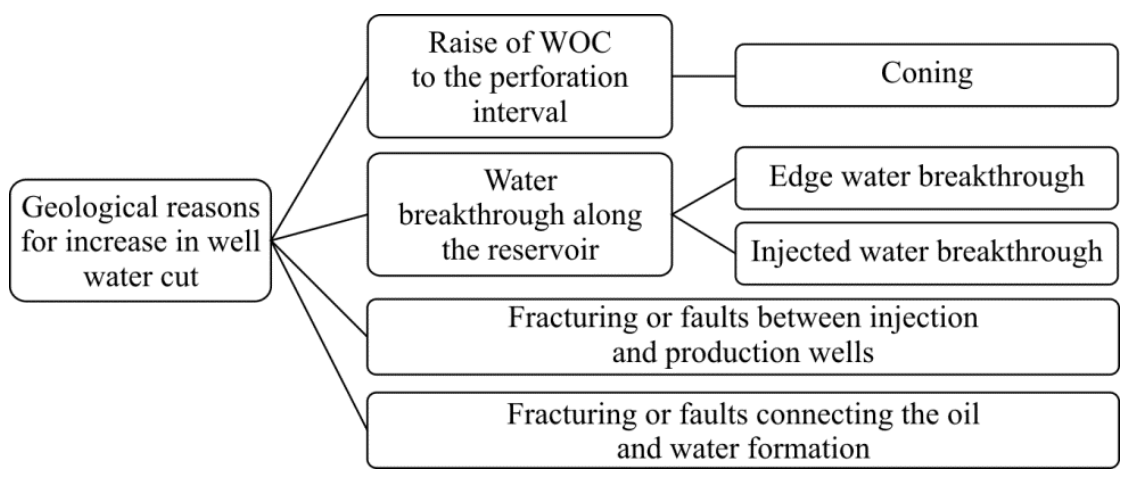

Fig. 3. Classification of geological reasons for increase in well water cut 
In order to classify the geological causes of increase in water cut, five basic scenarios of surplus water intering the bottom of the production well have been identified such as lifting of wateroil contact to the perforation interval, coning, water breakthrough along the reservoir, fracturing or faults between injection and production wells, fracturing or faults connecting the oil and water formation (Fig. 3).

\section{Analysis of dividing the wells by source of water}

There were water shut off jobs performed with various compositions at 50 production wells of the field considered Visean reservoir. Based on geophysical and hydrodynamic studies of wells, using chemical analytical and graphoanalytical methods, water sources have been identified before water shut off jobs [17-25]:

1) injected water breakthrough along the reservoir;

2) edge water breakthrough along the reservoir;

3) coning;

4) annular circulation;

5) leaks in production string.

There is a histogram given in Fig. 4 for a preliminary analysis of the sample that reflect distribution of sources of production well water cut increase with shut off jobs performed.

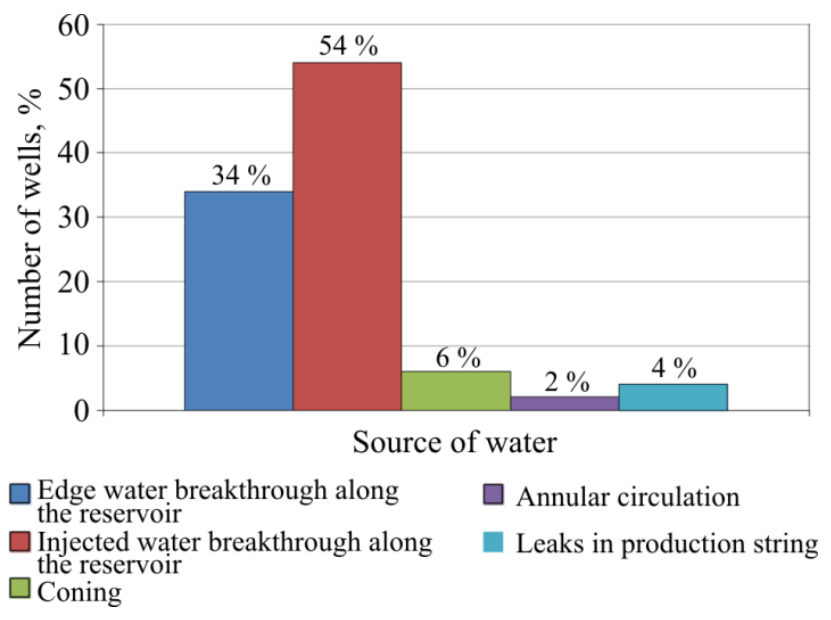

Fig. 4. Distribution of water sources at the Visean reservoir of Perm region field
The maximum number of wells corresponds to breakthroughs of edge water (34\%) and injected water $(54 \%)$ through the reservoir. Since that well groups make statistically significant samples, it was decided to use them for further analysis:

- well group 1 for injected water breakthrough;

- well group 2 for edge water breakthrough.

Student's $t$-criterion was used to analyze the average values of independent variables of two groups of well water sources [26-28] (Table 1).

Among the parameters analyzed, distance from a lower perforation hole to WOC, formation thickness and thickness of the interval of water inflow are statistically significant. Consequently, production wells with increased water cut caused by edge water breakthrough to the well bottom are characterized by a smaller value of the distance from a lower perforation hole to WOC, formation thickness and interval of the water inflow. On the other hand, difference between the initial and current density of water is not a statistically significant parameter, since the formation is flooded with purified water.

\section{Discriminant analysis of water sources}

Discriminant analysis is one of the most widely used in statistics of multidimensional methods. It is designed to classify the reservoir (assign to one of several specified groups in some optimal way) based on measuring various characteristics of a reservoir [29].

There are two the most commonly encountered sources of water in the Perm region field Visean reservoir identified such as breakthrough of injected water and breakthrough of edge water taht are well groups 1 and 2. Group 3 consists of 19 candidate wells selected for waterproofing works. In this case, discriminant analysis will help to assign each candidate well to one of two specific sources of water inflow, which will allow the water shut off technology to be chosen sufficiently $[12,30]$. 
In the paper, discriminant analysis was carried out using the Discriminant Analysis module of the Statistica 10 software. Models implemented in the module are linear, and classification functions and discriminant functions are linear combinations of observed values [29].
When carrying out the discriminant analysis, results were obtained that are as follows: the value of Wilks's lambda is 0.31 ; approximate value of the $F$-statistic with the number of degrees of freedom 22 and 94 is 3.32; $p$-significance level of the $F$-criterion is less than 0.00001 (Table 2).

Table 1

Values of Student's $t$-criterion for geological and technological parameters

\begin{tabular}{|c|c|c|c|c|c|c|c|}
\hline \multirow[b]{2}{*}{ Parameter } & \multicolumn{2}{|c|}{ Average } & \multirow{2}{*}{\begin{tabular}{|c|}
$\begin{array}{c}\text { Value of } \\
\text { Student's } \\
\text { criterion } \\
\text { Significance } \\
\text { level }\end{array}$ \\
\end{tabular}} & \multicolumn{2}{|c|}{ Number of observations } & \multicolumn{2}{|c|}{ Standard deviation } \\
\hline & group 1 & group 2 & & group 1 & group 2 & group 1 & group 2 \\
\hline Thickness of water inflow interval, $\mathrm{m}$ & 13.45 & 9.91 & $\frac{2.62}{0.01}$ & 27 & 17 & 5.13 & 2.67 \\
\hline Permeability, $\mu \mathrm{m}^{2}$ & 286.22 & 285.09 & $\frac{0.02}{0.99}$ & 27 & 17 & 227.61 & 245.67 \\
\hline Porosity, \% & 19.03 & 17.88 & $\frac{1.07}{0.29}$ & 27 & 17 & 3.29 & 3.76 \\
\hline Compartmentalization, units & 5.37 & 5.59 & $\frac{-0.23}{0.82}$ & 27 & 17 & 2.29 & 3.97 \\
\hline Sandiness, fractions & 0.35 & 0.31 & $\frac{1.39}{0.17}$ & 27 & 17 & 0.09 & 0.09 \\
\hline Net oil-bearing thickness, $\mathrm{m}$ & 13.23 & 12.34 & $\underline{0.53}$ & 27 & 17 & 5.10 & 5.87 \\
\hline Current reservoir pressure, $\mathrm{MPa}$ & 13.33 & 13.09 & $\frac{0.58}{0.56}$ & 27 & 17 & 1.56 & 0.88 \\
\hline Formation thickness, $\mathrm{m}$ & 29.00 & 9.19 & $\frac{6.00}{0.00}$ & 27 & 17 & 13.41 & 2.41 \\
\hline Current density of water, $\mathrm{g} / \mathrm{cm}^{3}$ & 1.07 & 1.11 & $\frac{-0.87}{0.39}$ & 27 & 17 & 0.21 & 0.02 \\
\hline $\begin{array}{l}\text { Viscosity of oil in reservoir } \\
\text { conditions, } \mathrm{mPa} \cdot \mathrm{s}\end{array}$ & 37.12 & 40.39 & $\frac{-1.19}{0.24}$ & 27 & 17 & 0.26 & 14.34 \\
\hline $\begin{array}{l}\text { Distance from the lower perforation } \\
\text { hole to WOC, } \mathrm{m}\end{array}$ & 24.29 & 13.41 & $\frac{3.19}{0.00}$ & 27 & 17 & 12.72 & 7.44 \\
\hline
\end{tabular}

N o t e : statistically significant parameters have red font.

Table 2

Summary table of data analysis

\begin{tabular}{|c|c|c|c|}
\hline Parameter & Wilks`s Lambda & Partial Lambda & Tolerance \\
\hline Thickness of water inflow interval, $\mathrm{m}$ & 0.32 & 0.99 & 0.72 \\
\hline Permeability, $\mu \mathrm{m}^{2}$ & 0.34 & 0.93 & 0.90 \\
\hline Porosity, \% & 0.34 & 0.92 & 0.72 \\
\hline Compartmentalization, units & 0.33 & 0.95 & 0.37 \\
\hline Sandiness, fractions & 0.32 & 0.97 & 0.21 \\
\hline Net oil-bearing thickness, $\mathrm{m}$ & 0.33 & 0.96 & 0.16 \\
\hline Current reservoir pressure, $\mathrm{MPa}$ & 0.32 & 0.97 & 0.84 \\
\hline Formation thickness, $\mathrm{m}$ & 0.49 & 0.65 & 0.75 \\
\hline Current density of water, $\mathrm{g} / \mathrm{cm}^{3}$ & 0.33 & 0.95 & 0.84 \\
\hline Viscosity of oil in reservoir conditions, $\mathrm{mPa} \cdot \mathrm{s}$ & 0.36 & 0.88 & 0.57 \\
\hline Distance from the lower perforation hole to WOC, $\mathrm{m}$ & 0.42 & 0.75 & 0.78 \\
\hline
\end{tabular}


The first column of Table 2 contain the Wilks's lambda values which are result of excluding the corresponding variable from the model [29]. The maximum values of Wilks's lambda are confined to the parameters "formation thickness" and "distance from the lower perforation hole to WOC". Therefore, presence of these variables in the discrimination procedure is most desirable.

Values of the partial lambda in the second column of Table 2 is the ratio of Wilks's lambda after adding the corresponding variable to the Wilks's lambda before adding this variable. A partial lambda characterizes the unit contribution of the corresponding variable to the deviding force of the model [29]. Minimum values of the partial lambda are also confined to parameters "formation thickness" and "distance from the lower perforation hole to WOC", which indicates their greatest contribution to general discrimination.

Tolerance is defined as $\left(R^{2}-1\right)$, where $R^{2}$ is the multiple correlation coefficient of this variable with all other variables in the model. As it is seen from Table 2, all variables with large tolerance values from 0.15 to 0.84 were successfully included in the model.

In order to obtain further results on discrimination of well groups with different sources of water, a canonical analysis was carried out. The linear discriminant functions given below are built based on the data characterizing the geological section of wells under study, properties of fluids produced, construction features and operation of wells.

The classification functions for groups 1 and 2 are as follows:

$Z_{1}$ (breakthrough of injected water $)=$

$=0.577 \cdot H_{\mathrm{w} . \mathrm{nf}}-0.001 \cdot K_{\mathrm{perm}}+3.285 \cdot K_{\mathrm{p}}-$

$-0.329 \cdot K_{\text {comp }}+85.731 \cdot K_{\text {sand }}-1.456 \cdot H_{\text {n.o.-b }}+$

$+5.682 \cdot P_{\text {res }}+0.572 \cdot H_{\text {res }}+56.784 \cdot \rho_{\text {liq }}+$

$+0.859 \cdot \mu_{\mathrm{o}}+0.383 \cdot H_{\mathrm{WOC}}-137.88$;

$Z_{2}$ (breakthrough of edge water) $=$

$=0.559 \cdot H_{\mathrm{w} . \mathrm{nn}}-0.001 \cdot K_{\mathrm{perm}}+3.303 \cdot \mathrm{K}_{\mathrm{p}}-$

$-0.227 \cdot K_{\text {comp }}+72.739 \cdot K_{\text {sand }}-1.262 \cdot H_{\text {n.o.-b }}+$

$$
\begin{aligned}
& +5.35 \cdot P_{\mathrm{res}}+0.373 \cdot H_{\mathrm{res}}+58.464 \cdot \rho_{\mathrm{liq}}+ \\
& +0.698 \cdot \mu_{\mathrm{o}}+0.252 \cdot H_{\mathrm{WOC}}-117.053
\end{aligned}
$$

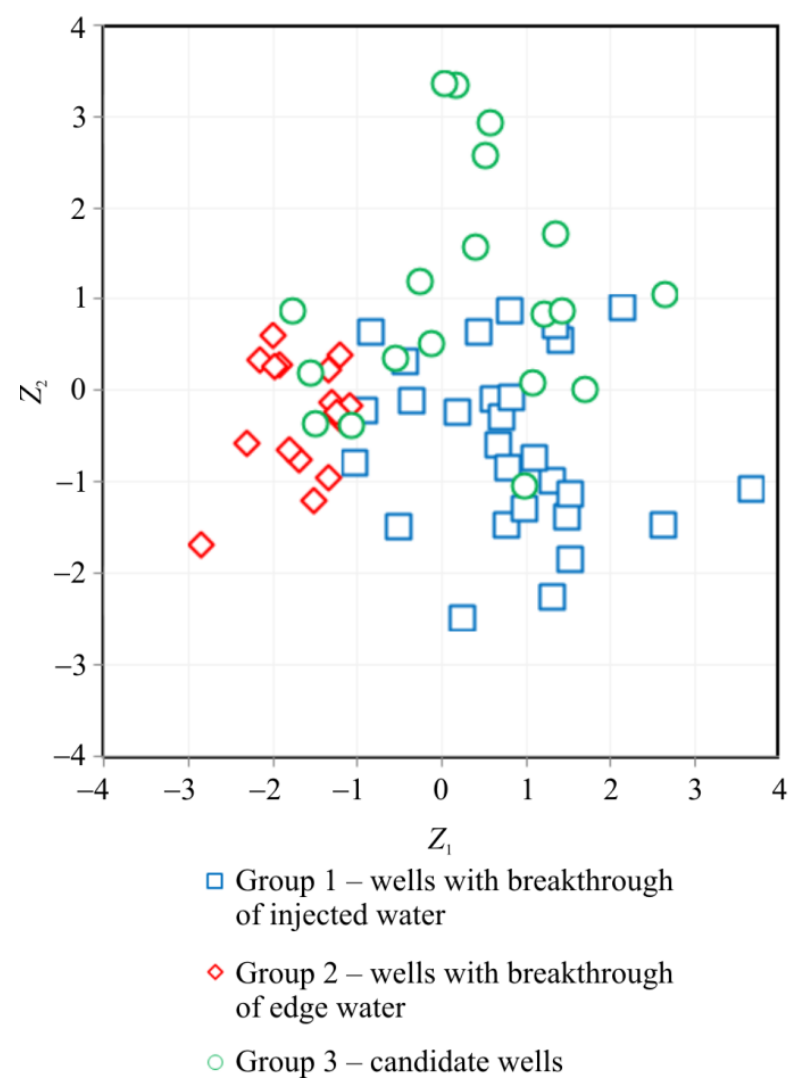

Fig. 5. Diagram of the scattering of canonical values for pairs of values of discriminant functions 1 and 2

Here, $H_{\text {w.inf }}-$ water inflow thickness, m; $K_{\text {perm }}-$ permeability coefficient, $\mu \mathrm{m}^{2}$; $K_{\mathrm{p}}-$ porosity coefficient, fractions; $K_{\text {comp }}-$ compartmentalization, units; $K_{\text {sand }}-$ sandyness coefficient, fractions; $H_{\text {n.o.-b }}-$ net oil bearing thickness, $\mathrm{m}$; $P_{\text {res }}-$ reservoir pressure, $\mathrm{MPa} ; H_{\text {res }}-$ reservoir thickness, $\mathrm{m}$; $\rho_{\text {liq }}-$ density of associated water, $\mathrm{g} / \mathrm{cm}^{3} ; \mu_{\mathrm{o}}-$ oil viscosity, $\mathrm{mPa} \cdot \mathrm{s} ; H_{\mathrm{WOC}}-$ distance from the lower perforation hole to WOC, $\mathrm{m}$. Thickness of the perforation interval in candidate wells is taken as thickness of water inflow interval.

According to the functions, values of $Z_{1}$ and $Z_{2}$ are calculated, which are shown in Fig. 5 for groups of wells with different water sources.

It can be seen from Fig. 5 that the values of $Z_{1}$ and $Z_{2}$ are fairly well separated within the studied groups of wells 1 and 2 . 
Table 3

Values of posterior probabilities

\begin{tabular}{|c|c|c|}
\hline $\begin{array}{c}\text { № of } \\
\text { candidate } \\
\text { well }\end{array}$ & $\begin{array}{c}\text { Group of wells 1. Source } \\
\text { of water - breakthrough } \\
\text { of injected water }\end{array}$ & $\begin{array}{c}\text { Group of wells } 2 \text {. Source } \\
\text { of water - breakthrough } \\
\text { of edge water }\end{array}$ \\
\hline 2116 & 0.031401 & 0.004083 \\
\hline 1122 & 0.433929 & 0.005930 \\
\hline 1131 & 0.790184 & 0.002493 \\
\hline 1177 & 0.018527 & 0.002342 \\
\hline 2118 & 0.536394 & 0.000225 \\
\hline 2133 & 0.132852 & 0.016871 \\
\hline 352 & 0.007677 & 0.002995 \\
\hline 1006 & 0.291668 & 0.273645 \\
\hline 328 & 0.007108 & 0.003815 \\
\hline 398 & 0.153802 & 0.089836 \\
\hline 411 & 0.169116 & 0.002178 \\
\hline 637 & 0.924416 & 0.012653 \\
\hline 680 & 0.227218 & 0.637236 \\
\hline 1005 & 0.070747 & 0.792262 \\
\hline 1032 & 0.348190 & 0.120381 \\
\hline 1104 & 0.700988 & 0.010679 \\
\hline 1120 & 0.102971 & 0.818458 \\
\hline 1141 & 0.453209 & 0.003616 \\
\hline 1181 & 0.033595 & 0.750752 \\
\hline
\end{tabular}

Note: Values of posteriori probabilities greater than 0.5 have red font.

Table 3 showing values of posteriori probabilities (belonging of candidate well to one of two groups of wells) is obtained as a result of discriminant analysis.
It was determined that out of 19 candidate wells for water shut off jobs 4 wells have high water cut due to breakthrough of water injected through the reservoir, 4 wells have high water cut due to breakthrough of edge water and 11 remaining candidate wells are likely to have a different source of water.

\section{Conclusions}

1. The sources of water cut in wells of the Perm region Visean reservoir are considered. The maximum number of wells is confined to two sources of water such as breakthrough along the reservoir of injected (group 1) or edge water (group 2).

2. The Student's $t$-criterion is used to analyze the average values of geological and technological parameters of two groups of wells obtained from the field data. It is found that production wells, which have high water cut due to breakthrough of edge water to a well bottom, are characterized by a lower distance from the bottom perforation hole to WOC, formation thickness and water inflow interval.

3. The discriminant analysis was carried out to determine the probabilities of assigning each of the 19 candidate wells to the $1^{\text {st }}$ and $2^{\text {nd }}$ groups of wells with different sources of water inflow.

\section{References}

1. Kudriashova D.A. Sovershenstvovanie algoritma podbora skvazhin-kandidatov dlia rabot po ogranicheniiu vodopritoka $\mathrm{s}$ primeneniem metodik identifikatsii istochnikov obvodneniia [Improvement of the algorithm for selection of candidate wells for works on water shut-off using methods of identification of water sources]. Sbornik rabot pobeditelei XXI Konkursa na luchshuiu molodezhnuiu nauchnotekhnicheskuiu razrabotku po problemam toplivnoenergeticheskogo kompleksa. Moscow, 2014, pp.249-255.

2. Beili B. et al. Diagnostika i ogranichenie vodopritokov [Diagnosis and water shut-off]. Neftegazovoe obozrenie, 2001, pp.44-67.
3. Elphick J., Seright R. A classification of water problem types. The Petroleum Network Education Conference's 3rd Annual International Conference on Reservoir Conformance Profile Modification "Water and Gas Shutoff". Houston, 1997, $126 \mathrm{p}$.

4. Daneshy A.A. Selection and execution criteria for water CONTROL treatments. Paper SPE 98059. SPE Symposium and Exhibition on Formation Damage Control. Lafayette, 2006. DOI: 10.2118/98059-MS

5. Kabir A.H., Bakar M.A., Salim M.A., Othman M., Yunos A. Water/gas shut-off candidates selection. Paper SPE 54357 presented at the 1999 SPE Asia Pacific Oil and Gas 
Conference and Exhibition. Jakarta, Indonesia, 20-22 April, 1999. DOI: 10.2118/54357-MS

6. Bailey B., Elphick J., Kuchuk F., Roodhart L. Water control. Oilfield Review, 2000, pp.30-51, available at: https://www.slb.com/ /media/ Files/resources/oilfield_review/ors00/spr00/p30_51.p df (accessed 14 September 2017).

7. Sparling D.D., Khagen R.U. Kontrol' i regulirovanie dobychi vody pri razrabotke mestorozhdenii [Control and regulation of water production in field development]. Neft', gaz $i$ neftekhimiia, 1984, no.3, pp.12-17.

8. Galkin V.I. et al. Razrabotka statisticheskoi modeli prognoza effektivnosti proppantnogo GRP po geologo-tekhnologicheskim pokazateliam dlia vereiskogo karboyatnogo neftegazonosnogo kompleksa [Development of a statistical model aimed at prediction of efficiency of proppant hydraulic fracturing of a formation, based on a reservoir geological-technological parameters, for Vereiskian carbonate oil- and gas-bearing complex]. Geologiia, geofizika $i$ razrabotka neftianykh $i$ gazovykh mestorozhdenii, 2017, no.3, pp.48-54.

9. Krivoshchekov S.N., Galkin V.I., Kozlova I.A. Determination of potentially oil bearing areas by behavioristical method by the example of Perm region (krai). Perm Journal of Petroleum and Mining Engineering, 2012, no.4, pp.7-15.

10. Safin D.K. Metodika veroiatnostnostatisticheskoi otsenki koeffitsienta izvlecheniia nefti iz zalezhei na razlichnykh stadiiakh ikh izuchennosti [The method of the probabilistic and statistical estimation of the oil recovery factor from deposits at various stages of their study]. Neft' i gaz, 2001, pp.63-66.

11. Shcherbenev A.V. Use of probabilistic and statistical methods for separation of rocks into permeable and impermeable parts (on example of clastic deposits of Visean stage of Sofyinskoe field). Perm Journal of Petroleum and Mining Engineering, 2017, vol.16, no.1, pp.14-22. DOI: 10.15593/2224-9923/2017.1.2

12. Gazizov A.Sh., Gazizov A.A. Povyshenie effektivnosti razrabotki mestorozhdenii na osnove ogranicheniia dvizheniia vod $\mathrm{v}$ plastakh [Increase in efficiency of field development on the basis of water shut-off in formations]. Moscow, NedraBiznestsentr, 1999, 285 p.

13. Muscat M. Physical principles of oil production. NY, McGraw-Hill Book Co, 1949, 142 p.

14. Telkov A.P., Stklianin Iu.P. Obrazovanie konusov vody pri dobyche nefti i gaza [Formation of water cones in oil and gas production]. Moscow, Nedra, 1965, $163 \mathrm{p}$.

15. Sazonov B.F. Nekotorye zakonomernosti obvodneniia neftianykh plastov [Some laws of water inflow of oil formations]. Moscow, Gosudarstvennyi nauchnotekhnicheskii institut khimicheskoi literatury, 1960,355 p.

16. Charnyi I.A. Podzemnaia gidrogazodinamika [Underground Hydro and Gas Dynamics]. Moscow, Gosudarstvennoe nauchno-tekhnicheskoe izdatel'stvo neftianoi i gorno-toplivnoi literatury, 1963, 397 p.

17. Gringarten Alain C. Well test analysis in practice. The Way Ahead, 2012, vol.08, iss.02, pp.10-14. DOI: 10.2118/0212-010-TWA

18. Lee J. Well testing. SPE, Richardson, TX, Eleventh Printing, 2002, 159 p.

19. Joseph J.A., Koederitz L.F. Unsteady-state spherical flow with storage and skin. Society of Petroleum Engineers Journal, 1985, vol.25, iss.06. DOI: 10.2118/12950-PA

20. Anisur Rahman N.M., Bin Akresh S.A., Al-Thawad F.M. Diagnosis and characterization of cross flow behind casing from transient-pressure tests. SPE Annual Technical Conference and Exhibition, 28-30 September, Houston, Texas, 2015. DOI: $10.2118 / 174999-M S$

21. Kremenetskiy M.I., Ipatov A.I., Kokurina V.V. Well-test interpretation in case of behind-the-casing crossflow. SPE Russian Oil and Gas Technical Conference and Exhibition, 28-30 October, Moscow, 2008. DOI: 10.2118/115323-MS

22. Chan K.S. Water control diagnostic plots. Paper SPE 30755. SPE Annual Technical Conference and Exhibition, 22-25 October, Dallas, Texas, 1995, pp.755-763. DOI: 10.2118/30775-MS 
23. God Egbe, Dulu Appah. Water coning diagnosis using special analysis. 29th Nigeria Annual International Conference and Exhibition, 1-3 August, Abuja, Nigeria, 2005. DOI: 10.2118/98816-MS

24. Yannis C. Yortsos, Youngmin Choi, Zhengming Yang, Piyush C. Shah. Analysis and interpretation of the water-oil ratio in waterfloods. SPE Annual Technical Conference and Exhibition, 5-8 October, San Antonio, Texas, 1997, pp.413434. DOI: $10.2118 / 38869-\mathrm{MS}$

25. Dahl J.A., Nguyen P.D., Dalrymple E.D., Rahimi A.B. Current water-control treatment designs. European Petroleum Conference, 16-18 November, Cannes, 1992. DOI: 10.2118/25029-MS

26. Pomorskii Iu.L. Metody statisticheskogo analiza eksperimental'nykh dannykh [Methods of statistical analysis of experimental data]. Leningrad, 1960, $174 \mathrm{p}$.

27. Lehmann E.L. The Fisher, NeymanPearson theories of testing hypotheses: one theory or two. Journal of the American Statistical Association, 1993, vol.88, no.424, pp.1242-1249. DOI: $10.2307 / 2291263$.

28. Pertsev. N.V. Kolichestvennye metody analiza i obrabotki dannykh [Quantitative methods of analysis and data processing]. Omsk, Izdatel'stvo Omskogo gosudarstvennogo universiteta, 2002, $142 \mathrm{c}$.

29. Kleshchenko I.I. et al. Teoriia i praktika remontno-izoliatsionnykh rabot $\mathrm{v}$ neftianykh i gazovykh skvazhinakh [Theory and practice of repair and shut-off works in oil and gas wells]. Tiumen', Ekspress, 2011, 386 p.

30. Mikhalevich I.M., Primina S.P. Primenenie matematicheskikh metodov pri analize geologicheskoi informatsii (s ispol'zovaniem komp'iuternoi informatsii) [Application of mathematical methods in analysis of geological information (using computer information)]. Irkutsk, Izdatel'stvo Irkutskogo gosudarstvennogo universiteta, 2006, 115 p.

\section{Библиографический список}

1. Кудряшова Д.А. Совершенствование алгоритма подбора скважин-кандидатов для работ по ограничению водопритока с применением методик идентификации источников обводнения // Сборник работ победителей XXI Конкурса на лучшую молодежную научно-техническую разработку по проблемам топливно-энергетического комплекса / Министерство энергетики Российской Федерации, Общероссийская общественная организация «Национальная система развития научной, творческой и инновационной деятельности молодежи России «Интеграция». - М., 2014. - С. 24-255.

2. Диагностика и ограничение водопритоков / Б. Бейли [и др.] // Нефтегазовое обозрение. 2001. - № 1. - C. 44-67.

3. Elphick J., Seright R. A Classification of water problem types // The Petroleum Network Education Conference's 3rd Annual International Conference on Reservoir Conformance Profile
Modification "Water and Gas Shutoff". - Houston; Texas, 1997. - $126 \mathrm{p}$.

4. Daneshy A.A. Selection and execution criteria for water control treatments // Paper SPE 98059. SPE Symposium and Exhibition on Formation Damage Control. Lafayette, 2006. DOI: 10.2118/98059-MS.

5. Water/gas shut-off candidates selection / A.H. Kabir, M.A. Bakar, M.A. Salim, M. Othman, A. Yunos // Paper SPE 54357 presented at the 1999 SPE Asia Pacific Oil and Gas Conference and Exhibition. Jakarta, Indonesia, 20-22 April, 1999. DOI: $10.2118 / 54357-M S$

6. Water control [Электронный pecypc] / B. Bailey, J. Elphick, F. Kuchuk, L. Roodhart // Oilfield Review. - 2000. - P. 30-51. - URL: https://www.slb.com/ /media/Files/resources/oilfie ld_review/ors00/spr00/p30_51.pdf (дата обращения: 14.09.2017).

7. Спарлинг Д.Д., Хаген Р.У. Контроль и регулирование добычи воды при разработке 
месторождений // Нефть, газ и нефтехимия. 1984. - № 3. - С. 12-17.

8. Разработка статистической модели прогноза эффективности проппантного ГРП по геолого-технологическим показателям для верейского карботатного нефтегазоносного комплекса / В.И. Галкин [и др.] // Геология, геофизика и разработка нефтяных и газовых месторождений. - 2017. - № 3. - С. 48-54.

9. Кривощеков С.Н., Галкин В.И., Козлова И.А. Определение перспективных участков геологоразведочных работ на нефть вероятностно-статистическими методами на примере территории Пермского края // Вестник Пермского национального исследовательского политехнического университета. Геология. Нефтегазовое и горное дело. - 2012. - № 4. C. 7-15.

10. Сафин Д.К. Методика вероятностностатистической оценки коэффициента извлечения нефти из залежей на различных стадиях их изученности // Нефть и газ. - 2001. № 4. - С. 63-66.

11. Щербенев А.В. Использование вероятностно-статистических методов для деления пород на проницаемую и непроницаемую части (на примере терригенных отложений визейского яруса Софьинского месторождения) // Вестник Пермского национального исследовательского политехнического университета. Геология. Нефтегазовое и горное дело. 2017 . - T. 16, № 1. - С. 14-22. DOI: $10.15593 / 2224-9923 / 2017.1 .2$

12. Газизов А.Ш., Газизов А.А. Повышение эффективности разработки месторождений на основе ограничения движения вод в пластах. М.: Недра-Бизнесцентр, 1999. - 285 с.

13. Muscat M. Physical principles of oil production. - NY.: McGraw-Hill Book Co, 1949. $142 \mathrm{p}$.

14. Телков А.П., Стклянин Ю.П. Образование конусов воды при добыче нефти и газа. - М.: Недра, 1965. - 163 с.
15. Сазонов Б.Ф. Некоторые закономерности обводнения нефтяных пластов. - М.: ГосНТИ химической литературы, 1960. - 355 с.

16. Чарный И.А. Подземная гидрогазодинамика. - М.: Государственное научнотехническое издательство нефтяной и горнотопливной литературы, 1963. - 397 с.

17. Gringarten Alain C. Well test analysis in practice // The Way Ahead. - 2012. - Vol. 08, iss. 02. - P. 10-14. DOI: 10.2118/0212-010-TWA

18. Lee J. Well testing. - SPE, Richardson, TX, Eleventh Printing, 2002. - 159 p.

19. Joseph J.A., Koederitz L.F. Unsteady-state spherical flow with storage and skin // Society of Petroleum Engineers Journal. - 1985. - Vol. 25, iss. 06. DOI: $10.2118 / 12950-\mathrm{PA}$

20. Anisur Rahman N.M., Bin Akresh S.A., Al-Thawad F.M. Diagnosis and characterization of cross flow behind casing from transient-pressure tests // SPE Annual Technical Conference and Exhibition, 28-30 September, Houston, Texas, 2015. DOI: $10.2118 / 174999-M S$

21. Kremenetskiy M.I., Ipatov A.I., Kokurina V.V. Well-test interpretation in case of behindthe-casing crossflow // SPE Russian Oil and Gas Technical Conference and Exhibition, 28-30 October, Moscow, 2008. DOI: 10.2118/115323-MS

22. Chan K.S. Water control diagnostic plots. Paper SPE 30755 // SPE Annual Technical Conference and Exhibition, 22-25 October, Dallas, Texas, 1995. - P. 755-763. DOI: 10.2118/30775-MS

23. God Egbe, Dulu Appah. Water coning diagnosis using special analysis // 29th Nigeria Annual International Conference and Exhibition, 1-3 August, Abuja, Nigeria, 2005. DOI: 10.2118/98816-MS

24. Analysis and interpretation of the water-oil ratio in waterfloods / C. Yortsos Yannis, Choi Youngmin, Yang Zhengming, C. Shah. Piyush // SPE Annual Technical Conference and Exhibition, 5-8 October, San Antonio, Texas, 1997. - P. 413434. DOI: $10.2118 / 38869-\mathrm{MS}$ 
25. Current water-control treatment designs / J.A. Dahl, P.D. Nguyen, E.D. Dalrymple, A.B. Rahimi // European Petroleum Conference, 16-18 November, Cannes, 1992. DOI: $10.2118 / 25029-\mathrm{MS}$

26. Поморский Ю.Л. Методы статистического анализа экспериментальных данных: монография. - Л., 1960. - 174 с.

27. Lehmann E.L. The Fisher, NeymanPearson theories of testing hypotheses: one theory or two // Journal of the American Statistical Association. - 1993. - Vol. 88, № 424. - P. 12421249. DOI: $10.2307 / 2291263$.
28. Перцев. Н.В. Количественные методы анализа и обработки данных: учеб. пособие. Омск: Изд-во Омск. гос. ун-та, 2002. - 142 с.

29. Теория и практика ремонтноизоляционных работ в нефтяных и газовых скважинах / И.И. Клещенко [и др.]. - Тюмень: Экспресс, 2011. - 386 с.

30. Михалевич И.М., Примина С.П. Применение математических методов при анализе геологической информации (с использованием компьютерной информации). - Иркутск: Изд-во Иркут. гос. ун-та, 2006. -115 c.

Please cite this article in English as:

Kudryashova D.A. Use of probabilistic and statistical methods for determination of the sources of water flow in candidate wells for water shut-off works (on example of the Visean reservoir of the Perm region field). Perm Journal of Petroleum and Mining Engineering, 2018, vol.17, no.1, pp.26-36. DOI: 10.15593/2224-9923/2018.1.3

Просьба ссылаться на эту статью в русскоязычных источниках следующим образом:

Кудряшова Д.А. Использование вероятностно-статистических методов для определения источников обводнения скважинкандидатов для водоизоляционных работ (на примере визейского объекта месторождения Пермского края) // Вестник Пермского национального исследовательского политехнического университета. Геология. Нефтегазовое и горное дело. 2018. - T.17, №1. - С.26-36. DOI: 10.15593/2224-9923/2018.1.3 